\title{
GEOGRAPHIC DISTRIBUTION OF PROTECTED SEDGE SPECIES Carex Pilosa Scop. IN LATVIA WITH REFERENCE TO FOREST ECOSYSTEMS
}

\author{
Edgars Iliško, Juris Soms \\ Daugavpils University, Faculty of Nature Sciences and Mathematics \\ Parādes st.1, Daugavpils, LV 5401, Latvia \\ Ph.: +37128663100,e-mail: edgars_ilisko@inbox.lv; juris.soms@du.lv
}

\begin{abstract}
The results of field studies, laboratory research and desk-based GIS geospatial analysis of ecological factors which determine geographic distribution of hairy sedge (Carex Pilosa Scop.) in Latvia with reference to forest ecosystems are presented in this article. Hitherto such a complex studying of chorology and ecology of this protected forest herb has not been performed before in Latvia, nor has it been attempted in the other Baltic states. The obtained results demonstrate that this protected plant species ecologically is quite plastic regarding its growing conditions and can be found in different forest ecosystems, however the most vital and largest cenopopulations of Carex pilosa are associated with the old deciduous forests, particularly those growing within erosion landforms on the slopes of the southern or south-eastern aspect. This research is important both from the scientific and practical view point, allowing to work out recommendations for the protection and conservation of this rare species in Latvia.
\end{abstract}

Keywords: Carex pilosa, chorology, ecological factors, forest ecosystems.

\section{Introduction}

Hairy sedge Carex pilosa Scop. ranges in the temperate climate zone of Eurasia, and occurrence of this herb in the northern part of the continent in general corresponds to the biogeographic regions of oak distribution. Although hairy sedge is rather widespread in Central Europe, where in Oak-Hornbeam woods this species can form large, even squarekilometres stands within which any other herbaceous plants can grow [1,2], in Latvia it is very rare, because the north-western edge of this plant growing areal crosses the south-eastern part of Latvia. This species of sedge belonging to the family Cyperaceae is included in the $1^{\text {st }}$ category of the Red Data Book of Latvia [3], as well as in the list of protected plant species of Latvia [4]. According to Ellenberg [5], Carex pilosa is hemicryptophyte species of the thermophilic - close to partially thermophilic group, with moderate demands on nutrients. At a distance this forest herb looks similar to other sedges. However, with a closer look, this species can be distinguished easily from other common sedges by evergreen leaves, which are the best indicators of this species - in contradistinction to other Carex species growing in Latvia it has hairs alongside the central string and margin of the narrow leaf blade. This species is early flowering plant, which in Latvia usually flowers in the end of April beginning of May. During flowering flower stalk usually carries one male inflorescence spike on the top and one or two female spike lower down; the female spike has more subtle white stigmas.

Carex pilosa for the first time was recorded in south-eastern part of Latvia in 1939 [6], within one of the gullies which dissect the right slope of the Daugava valley near the Juzefova village and for a long time had been regarded as rarity of Latvia flora. However, since 2002, when inventory of species of EU Habitat Directive (Annex I and II) [7] was performed in Latvia, six new records of this sedge were found in south-eastern part of country. In recent years complex research programme is undertaken at Daugavpils University to study chorology and ecology of this forest plant, and since 2008 authors found two more records [8]. Thus at the present moment 10 records of this protected plant species are documented in 
Latvia [8, 9]. Although documenting of all known Carex pilosa records in Latvia for botanical data bases and herbariums is completed, the extent to which ecological factors controlling the distribution of this species and regularities of its chorology are currently studied is insufficient.

In order to get insight into these issues and to elucidate the regularities of geographic location of hairy sedge with reference to forest ecosystems, detailed studies of all records were performed in situ. The specific objectives of the study presented in this article were (1) to aggregate information stored in data bases about precise geographic location of Carex pilosa records in Latvia; (2) to carry out reconnaissance and survey of all cenopopulations of sedge by precise delineation and mapping of them by high-accuracy GPS; (3) to obtain data on the physiogeographic, ecological and habitat characteristics of all Carex pilosa populations during the field expeditions; (4) to perform laboratory analysis of soil samples from Carex pilosa records in order to estimate nutrient content and $\mathrm{pH}$; (5) to process GPS survey data and to digitize GIS thematic layers with subsequent preparing of large-scale maps of hairy sedge records, including maps of digital elevation models and slope aspects; (6) to carry out complex mathematical and geospatial analyses of the obtained data by GIS tools in order to elucidate ecogeomorphological aspects and abiotic factors controlling spatial distribution of this perennial evergreen sedge in respect of landforms type, slope aspect and gradient, and forest habitat.

Hitherto such a complex studying of factors controlling geographic distribution of this protected forest herb has not been performed before in Latvia, nor has it been attempted in the other Baltic countries. Consequently, the obtained data contribute to a better understanding of the ecology of Carex pilosa in Northern Europe and enhance our knowledge about chorology of this species with reference to forest ecosystems.

\section{Materials and methods}

The results presented in the article are based on original data obtained in course of 33 expeditions and the research programme carried out in 2008 - 2010. Various methods and techniques were applied in order to achieve the objectives stated in Introduction of this article. In general, research was done in four main directions, i.e. aggregation and analysis of the data, field studies, laboratory research and desk-based studies by GIS tools.

Aggregating and analysing of the data about records of Carex pilosa in Latvia was carried out by searching through data bases of the Ministry of Environment of Latvia and Latvian Botanical Society, as well as by examination of herbariums of University of Latvia (LATV) and Daugavpils University (DAU). It allows to get precise geographic location of hairy sedge records within the study area for further field research.

Thereafter field studies of the identified Carex pilosa records were carried out including reconnaissance all cenopopulations, survey and precise delineation of them by THALES MobileMapperCE GPS (a maximum error up to several meters), description of tree and plant species composition of forest, soil sampling and identification of topographic characteristics of records (e.g. aspect of slope, its gradient and profile, type and morphometry of landforms etc). The last tasks were done with the help of standard geomorphological techniques $[10,11]$. Slope profiles with location of Carex pilosa records on them were generated by AutoCAD 2008 LT software from the data collected during measurement of slope gradients along the sampling line. In turn these measurements were performed by precise oil damped AngleLevel clinometer (error $\pm 0.5^{\circ}$ ) placed on the rod of $1 \mathrm{~m}$ length, hence reducing impact of microtopography. The description of tree and plant species composition recognized in records further was used to identify the type of forest habitats.

Field studies of the sedge Carex pilosa was performed in ten records situated in the southeastern part of Latvia (Fig 1.). Three of these records are located in the Daugava spillway 
valley within the Nature Park "Daugavas Loki", one in the river Lazdukalna valley (left tributary of the Daugava in the Nature Park "Daugavas Loki”), one in the river Puņiška valley (right tributary of the Daugava in the Nature Park "Daugavas Loki"), another two in the Rubenu brooklet and the Dubezers tunnel valley within the Nature Reserve "Pilskalnes Siguldina", large record consisting of many smaller patches located in the Nature Reserve "Raudas Meži", one on the Lakstīgalu island in the Nature Reserve "Zvirgzdenes ezera salas", and the last one near Dūdel̦i village on the southern edge of the Latgale upland.

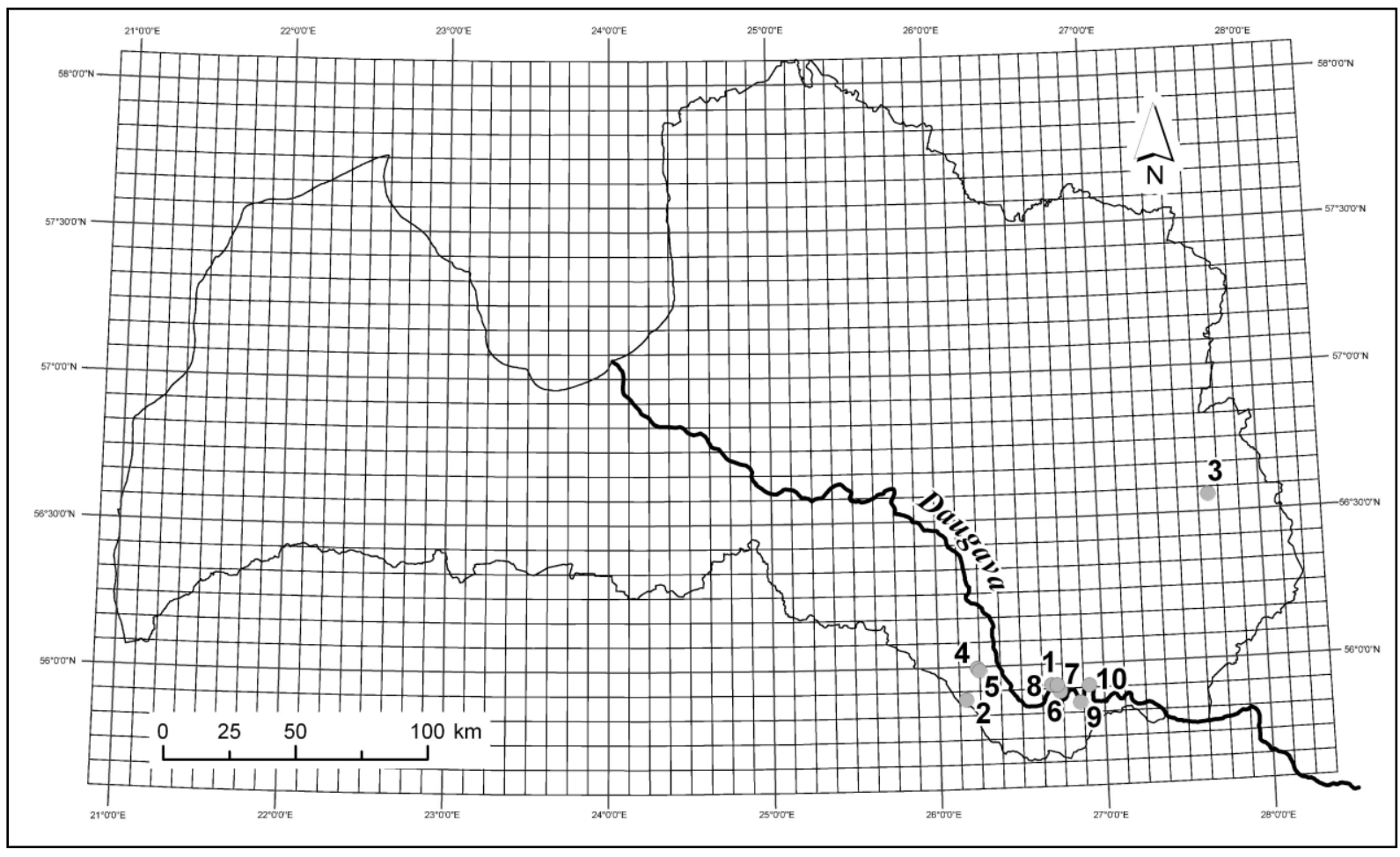

Fig 1. Location of all records of the hairy sedge Carex pilosa Scop. in the south-eastern part of Latvia.

Number of record in the map in chronological sequence of finding: 1 - the gully Baznīcas grāvis (the Nature Park "Daugavas loki"); 2 - the river Ilūkste valley (the Nature Reserve "Raudas Meži”); 3 - the Lakstīgalu island (the Nature Reserve "Zvirgzdenes ezera salas"); 4 - the Dubezers tunnel valley (the Nature Reserve "Pilskalnes Siguldina"); 5 - the Rubenu brooklet (the Nature Reserve "Pilskalnes Siguldiņa"); 6 - the gully Peščanij ručej (the Nature Park "Daugavas loki”"); 7 - the park Juzefova (the Nature Park "Daugavas loki"); 8 - village Dūdelıi (the edge of the Latgale upland); 9 - the river Lazdukalna valley (the Nature Park "Daugavas loki"); 10 - the river Puṇiška valley (the Nature Park "Daugavas loki”)

During field expeditions ten soil samples were taken from O-horizon of each Carex pilosa record. These samples subsequently were analysed according to standard methods (LVS ISO 10390:2006) in the Laboratory of Environmental Chemistry, Daugavpils University, in order to identify chemical parameters of soil, $\mathrm{pH}_{\mathrm{KCl}}$ and $\mathrm{pH}_{\mathrm{H}_{2} \mathrm{O}}$ in particular.

Finally, mathematical and geospatial analyses of the obtained data were carried out by GIS tools. For these purposes as data processing platform was used ESRI ArcGIS software, which was applied for procedures of digitizing, for converting and integrating GPS data into GIS thematic layers, for creating digital elevation models and preparing of maps, as well as for calculation of topographic parameters and geospatial analysis of ecogeomorphological aspects and abiotic factors controlling spatial distribution of Carex pilosa. 


\section{Results and discussion}

Obtained results, first of all, show direct interconnection between location of Carex pilosa records and landforms, in particular negative erosion forms. In fact the largest part, i.e. seven from ten known records of hairy sedge are located exactly within river valleys, gullies, tunnel valleys and spillway valleys. Secondly, data obtained during direct reconnaissance in situ and large scale analysis of information derived by overlaying of GIS thematic layers show, that large stands of this plant spatially is associated with forest ecosystems, i.e. forest habitats of different types (Table 1.).

Canopy vegetation in the records under study mainly is represented by broad-leaved or deciduous forests. The main stand-forming tree species in the Daugava spillway valley, the river Lazdukalna valley, the Lakstiggalu island and the Rubenu brooklet study sites are wych elm (Ulmus glabra Huds.), linden (Tilia cordata Mill.) and oak (Quercus robur), hazel (Corylus avellana L.) occur only in undergrowth, whilst in the river Ilūkste valley record within the Nature Reserve "Raudas meži" and the Dubezers tunnel valley prevails aspen (Populus tremula L.) with admixture of ash (Fraxinus excelsior L.) and oak (Quercus robur L.). In such broad-leaved or deciduous forests during the sedge flowering and development in spring sunlight can penetrate through the open structure of the tree layer right to the ground where the xero-thermophilous Carex pilosa, which is dominating in the herb layer, can find acceptable conditions.

Considering such combination of abiotic geomorphological factors and composition of forest habitats, it is possible to assume that recognized geographic distribution of Carex pilosa had formed as result of human activities, when broad-leaved forests on nutrient-rich soils were cut off in order to establish fields of arable land. In this case remnant patches of broad leaved forest on the steep slopes unsuitable for soil cultivation and other agricultural needs became as a kind of refuge for hairy sedge. Partially this assumption was proved by the desk-based studies of historical topographic maps published in 1917, 1928, 1936 and 1972, and comparison of them with aerial photographs flown in 2005. Cartographic analysis of this information sources reveal the long-term presence of woodlands in majority of localities, where records of Carex pilosa had been found. However, to get better understanding about ecological factors controlling geographic distribution of this species, detailed analysis of topographic characteristics were performed by GIS.

The GIS analysis of digital elevation models of the study sites show that to a great extent distribution of the sedge is related to the sunniest and warmest forest habitats on southern, south-eastern and south-western slopes of river valleys and gullies in the region under study (Fig 2.). The influence of dryness and warmth can be well observed by comparing similar canopy vegetation with that of the slopes of north-, north-western- or north-eastern-spacing where Carex pilosa occurs sporadically and does not form large stands. Simultaneously it is necessary to highlight, that inclination of slopes within records, where the sedge was found, varies from $5^{\circ}$ to $20^{\circ}$, however, in majority of sites it exceeds $15^{\circ}$ (Table 1 .).

In this case topographic features, i.e. aspect and gradient of slope determine the spatial distribution of Carex pilosa within landforms, because steeper slopes of S, SE or SW aspect receive more solar energy and thus warm up faster and to higher degree than gentler slopes of other exposure.

Laboratory analysis of soil samples demonstrates that soil type in records is mainly presented by luvisol, developed on stony and gravelly sandy loam of glacial origin (moraine). These relatively dry soils have $\mathrm{pH}_{\mathrm{KCl}}$ and $\mathrm{pH}_{\mathrm{H}_{2} \mathrm{O}}$ values, which ranges from 5.36 to 7.58 and 5.83 to 8.0 respectively. 
Table 1.

The characteristics of main records of hairy sedge in south-eastern part of Latvia

\begin{tabular}{|c|c|c|c|c|}
\hline $\begin{array}{c}\text { Geographical location of } \\
\text { record }\end{array}$ & $\begin{array}{l}\text { Location with } \\
\text { reference to land } \\
\text { form }\end{array}$ & \begin{tabular}{|c|} 
The \\
average \\
slope (in \\
record) \\
\end{tabular} & \begin{tabular}{|c|} 
The \\
dominant \\
slope \\
aspect \\
\end{tabular} & Habitat \\
\hline $\begin{array}{l}\text { The gully Baznīcas grāvis (The } \\
\text { Nature Park "Daugavas loki") }\end{array}$ & Slope of the gully & $23^{\circ}$ & $\mathrm{S} ; \mathrm{SE}$ & $\begin{array}{l}\text { Wych elm-oak } \\
\text { rich broad- } \\
\text { leaved forest }\end{array}$ \\
\hline $\begin{array}{l}\text { The gully Peščanij ručej (The } \\
\text { Nature Park "Daugavas loki”) }\end{array}$ & Slope of the gully & $31^{\circ}$ & SW & $\begin{array}{l}\text { Mixed } \\
\text { deciduous } \\
\text { forest }\end{array}$ \\
\hline $\begin{array}{l}\text { The river Puniška valley, record } \\
\text { No } 1 \text { (The Nature Park } \\
\text { "Daugavas loki") }\end{array}$ & $\begin{array}{l}\text { The left slope of } \\
\text { the river Puniška } \\
\text { valley }\end{array}$ & $20^{\circ}$ & $\mathrm{S} ; \mathrm{SE}$ & $\begin{array}{l}\text { Grey alder } \\
\text { forest }\end{array}$ \\
\hline $\begin{array}{l}\text { The river Lazdukalna valley } \\
\text { (Daugava spillway valley) }\end{array}$ & $\begin{array}{l}\text { Slope of the river } \\
\text { valley }\end{array}$ & $18^{\circ}$ & SW & $\begin{array}{l}\text { Wych elm- } \\
\text { lime rich } \\
\text { broad-leaved } \\
\text { forest }\end{array}$ \\
\hline $\begin{array}{l}\text { The Rubeñu brooklet (The } \\
\text { Nature Reserve "Pilskalnes } \\
\text { Siguldina,") }\end{array}$ & Slope of the gully & $26^{\circ}$ & SE & $\begin{array}{l}\text { Mixed } \\
\text { deciduous } \\
\text { forest }\end{array}$ \\
\hline $\begin{array}{l}\text { The Dubezers tunnel valley } \\
\text { (The Nature Reserve } \\
\text { "Pilskalnes Siguldina") }\end{array}$ & $\begin{array}{l}\text { Slope of the tunnel } \\
\text { valley }\end{array}$ & $16^{\circ}$ & SW & $\begin{array}{l}\text { Mixed } \\
\text { deciduous } \\
\text { forest }\end{array}$ \\
\hline $\begin{array}{l}\text { The river Ilūkste valley, patch } \\
\text { No } 1 \text { (The Nature Reserve } \\
\text { "Raudas Meži") }\end{array}$ & $\begin{array}{l}\text { The right slope of } \\
\text { the Ilūkste valley }\end{array}$ & $12^{\circ}$ & SW & $\begin{array}{l}\text { Aspen rich } \\
\text { deciduous } \\
\text { forest }\end{array}$ \\
\hline $\begin{array}{l}\text { The river Ilūkste valley, patch } \\
\text { No } 2 \text { (The Nature Reserve } \\
\text { "Raudas Meži") }\end{array}$ & $\begin{array}{l}\text { The right slope of } \\
\text { the Ilūkste valley }\end{array}$ & $15^{\circ}$ & SW & $\begin{array}{l}\text { Aspen rich } \\
\text { deciduous } \\
\text { forest }\end{array}$ \\
\hline $\begin{array}{l}\text { The river Ilūkste valley, patch } \\
\text { No } 5 \text { (The Nature Reserve } \\
\text { "Raudas Meži") }\end{array}$ & $\begin{array}{l}\text { The slope of the } \\
\text { gully within Ilūkste } \\
\text { valley }\end{array}$ & $21^{\circ}$ & $\mathrm{S} ; \mathrm{SE}$ & $\begin{array}{l}\text { Mixed } \\
\text { deciduous } \\
\text { forest }\end{array}$ \\
\hline $\begin{array}{l}\text { The river Puniška valley, record } \\
\text { No } 2 \text { (The Nature Park } \\
\text { "Daugavas loki") }\end{array}$ & $\begin{array}{l}\text { The right slope of } \\
\text { the river Puniška } \\
\text { valley }\end{array}$ & $5^{\circ}$ & SW & $\begin{array}{l}\text { Grey alder } \\
\text { forest }\end{array}$ \\
\hline $\begin{array}{l}\text { The Lakstīgalu island (The } \\
\text { Nature Reserve "Zvirgzdenes } \\
\text { ezera salas") }\end{array}$ & $\begin{array}{l}\text { The middle part of } \\
\text { the SE slope of the } \\
\text { island }\end{array}$ & $4^{\circ}$ & SE & $\begin{array}{l}\text { Lime rich } \\
\text { broad-leaved } \\
\text { forest }\end{array}$ \\
\hline
\end{tabular}




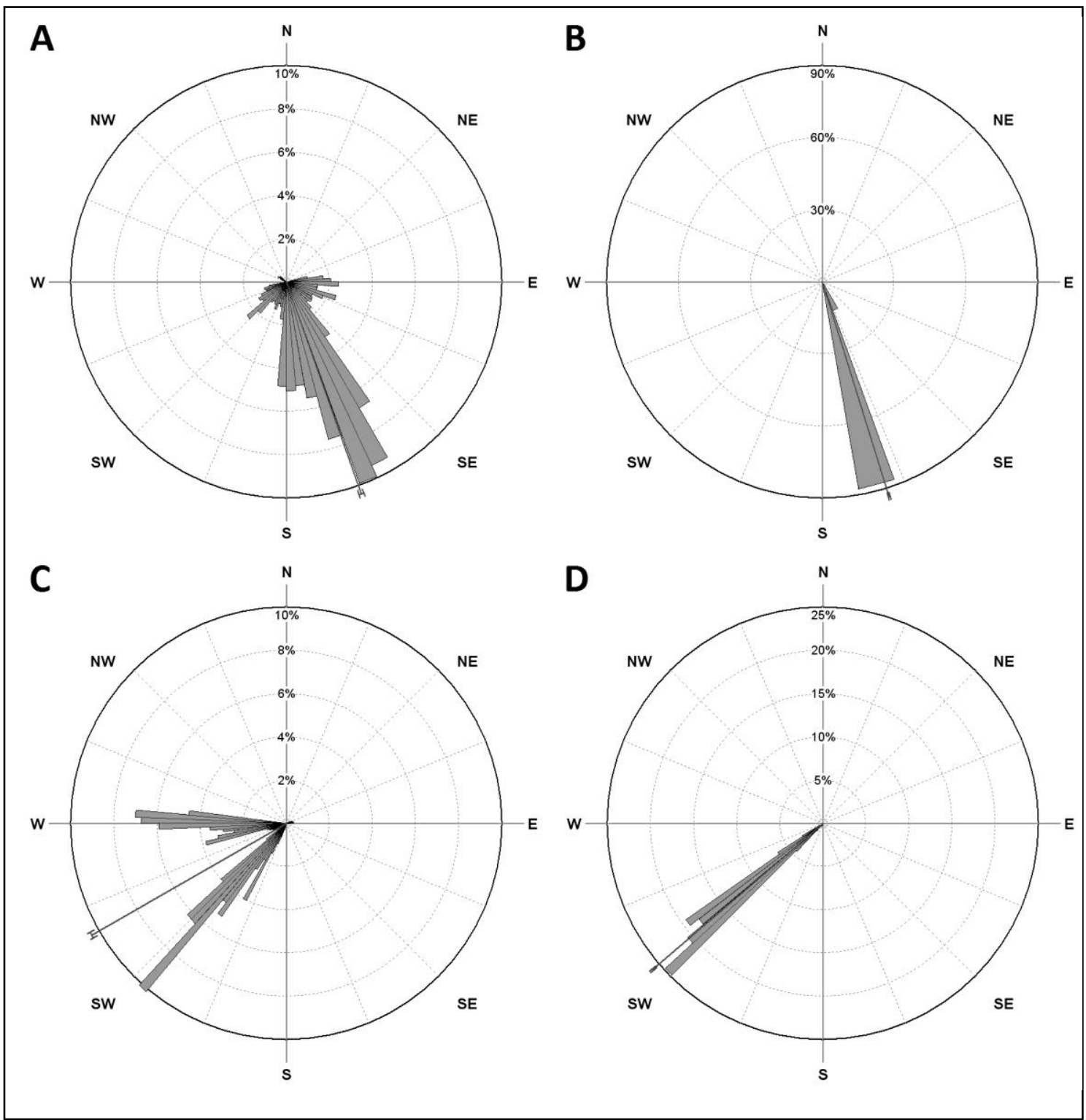

Fig 1. Rose diagrams of hairy sedge Carex pilosa relative distribution (in percents from total area of record) on the slopes of different aspect within selected records:

A - the gully Baznīcas grāvis (the Nature Park "Daugavas loki"); B - the Rubenu brooklet (the

Nature Reserve "Pilskalnes Siguldiņa"); C - the river Lazdukalna valley (the Nature Park

"Daugavas loki"); D - the Dubezers tunnel valley (the Nature Reserve "Pilskalnes Siguldiṇa")

\section{Conclusions}

The results of the given research permit to draw several important conclusions about the factors controlling geographic distribution of Carex pilosa with reference to forest ecosystems in south-eastern Latvia.

1. Alongside topography and soil type, forest habitat of the record is the principal one that affects spatial distribution of Carex pilosa, because the ecology of this species determine the presence of forest ecosystem as prerequisite for its favourable growing, in contrary the decreasing of Carex pilosa cenopopulations was observed in places, where former woodlands had been transformed into clearings after forest cut-off.

2. The spatial distribution of Carex pilosa can be explained as result of interaction of indirect and direct controlling factors. On the one hand, growing of the sedge within erosion forms is a result of preservation of forest habitats due to steep slopes. On the 
other hand, development of erosion landforms within landscape causes formation of environment favourable for existence of Carex pilosa due to slope aspect, slope gradient, soil properties and amount of solar radiation. Hence results highlight the positive role of geomorphological factors in formation of different habitats and increasing of biodiversity.

3. Carex pilosa is growing mainly on the steeper sunlit slopes of south, south-eastern or south-western aspect under broad leaved or deciduous vegetation where solar radiation can reach the ground through the tree layer.

4. The hairy sedge grows in relatively dry places with soil $\mathrm{pH}$ values near to neutral, or slightly alkaline or acid, where in spring, before formation of leaves, soil surface are warmed up by direct sunlight.

5. Further findings of this species can be expected in similar habitats in neighbouring areas of Latvia and Lithuania, particularly in V-shaped deep river valleys and gullies within uplands of Baltic morainic ridge, e.g. the Augšzeme Upland and the Aukštaitijos Upland.

\section{Acknowledgment}

Research reported in this article was supported by the ESF project No. 2009/0151/1DP/1.1.2.1.1/09/IPIA/VIAA/012 "Support of master's studies in Daugavpils University"

\section{References}

1. Rejzková, E., Fér, T., Vojta, J., Marhold, K. Phylogeography of the forest herb Carex pilosa (Cyperaceae). Botanical Journal of the Linnean Society, 158 (1), 2008, pp.115-130.

2. Ellenberg, H. Vegetation ecology of Central Europe. $4^{\text {th }}$ edit. Cambridge University Press, Cambridge, UK, 2009, 756 pp.

3. Baroniņa, V. Matainais grīslis. Grām.: Latvijas Sarkanā grāmata. Andrušaitis G. (Ed), 3. sēj: Vaskulārie augi. Rīga, LU Biolog̣ijas institūts, 2003, 126.lpp.

4. Latvijas Republikas Ministru kabineta noteikumi Nr.396 „Noteikumi par īpaši aizsargājamo sugu un ierobežoti izmantojamo īpaši aizsargājamo sugu sarakstu", 2000. Latvijas Vēstnesis, Nr. 413/417 (2324/2328),, 17.11.2000. ar grozījumiem: 27.07.2004. MK noteikumi Nr.627, Latvijas Vēstnesis, Nr. 120 (3068), 30.07.2004.) [spēkā ar 31.07.2004.].

5. Ellenberg, H. Zeigerwerte der Gefässpflanzen Mitteleuropas. Scripta Geobotanica, IX (Göttingen). 1974, $97 \mathrm{pp}$.

6. Villerts, A. Dažu 1939. gadā ievākto retāko augu atradnes. Daba un Zinātne. Nr.3. 1940, 100.-101.lpp.

7. European Council Directive 92/43/EEC of 21 May 1992 on the conservation of natural habitats and of wild fauna and flora. Official Journal of the European Community, L 206 , 22/07/1992, pp. 0007 - 0050.

8. Iliško, E., Soms, J. Matainā grī̌ş̦a Carex pilosa Scop. izplatība dienvidaustrumu Latvijāa Krāj.: Ģeogrāfija. Ģeolog̣ija. Vides zinātne. Latvijas Universitātes 68. zinātniskās konferences referātu tēžu krājums. Rīga, LU Akad. apgāds, 2010, 87.-89.lpp.

9. Gudžinskas, Z., Krampis, I., Laiviņš M. Spread of Carex pilosa Scop. In Latvia and Lithuania. Latvijas Veǵetācija, 21, 2010, pp.127-132.

10. Young, A., Brunsden, D., Thornes, J.B. Slope profile survey. British Geomorphological Research Group Bulletin No. 11. Geo Abstracts, Norwich, 1974, 52 p.

11. Goudie, A., Anderson, M., Burt, T., Lewin, J., Richards, K., Whalley, B., Worsley, P. Geomorphological techniques. $2^{\text {nd }}$ ed. Routledge, London, 1998, 570 pp.

Anotācija. Rakstā ir izklāstīti lauka, laboratorisko un kamerālo pētījumu un GIS geotelpiskās analīzes rezultāti par ekologiskajiem faktoriem, kuri nosaka augu sugas - matainā grīšļa (Carex pilosa Scop.) geogrājisko izvietojumu Latvijā saistī̄ā ar meža ekosistēmām. Lìdz šim padzilinināti kompleksa rakstura šìs aizsargājamās augu sugas horologíijas un ekologijas pētījumi nedz Latvijā, nedz citās Baltijas valstīs nav veikti. Iegūtie rezultāti parāda, ka suga ekologiski ir diezgan plastiska augšanas apstāklu ziñā un ir sastopama dažāda tipa mežu ekosistēmās, tomēr vitālākās un lielākās matainā grīšlı audzes ir saistìtas ar veciem platlapju mežiem, it sevišķi tiem, kas aug erozijas reljefa formās uz dienvidu-dienvidaustrumu ekspozīcijas nogāzēm. Veiktie pêtījumi ir nozīmīgi gan no zinātniskāa, gan no praktiskā viedokḷa, jo ļauj izstrādāt ieteikumus šis retās sugas saglabāšanai un aizsardzībai Latvijā. 